\title{
Macroparasites in cetaceans stranded on the northwestern Spanish Atlantic coast
}

\author{
E. Abollo ${ }^{1}$, A. López ${ }^{2}$, C. Gestal ${ }^{1}$, P. Benavente ${ }^{3}$, S. Pascual ${ }^{1, *}$ \\ ${ }^{1}$ Laboratorio de Parasitología, Facultad de Ciencias del Mar, Universidad de Vigo, Apdo. 874, E-36200 Vigo, Spain \\ ${ }^{2}$ C.E.M.MA. Anxeriz, 19, 5º D. Milladoiro, E-15895 Ames, A Coruña, Spain \\ ${ }^{3}$ C.E.S. Apto. 100, O Grove, E-36980 Pontevedra, Spain
}

\begin{abstract}
An extensive parasitological survey was carried out during autopsy of 80 cetaceans representing 8 species within 4 families (Delphinus delphis, Stenella coeruleoalba, Tursiops truncatus, Grampus griseus, Globicephala melas, Kogia breviceps, Phocoena phocoena and Megaptera novaeangliae) collected on the northwestern Spanish Atlantic coast from February 1991 to October 1996. Two species of tetraphyllidean cestodes (Phyllobothnum delphini and Monorygma grimaldii), 2 ascaridoid nematodes (Anisakis simplex and $A$. physeteris), a single spirurid nematode (Crassicauda magna), 4 rhabditidiform nematodes (Halocercus delphini, H. invaginatus, Halocercus spp. and Stenurus globicephalae), a single polymorphynae acanthocephalan (Bolbosoma sp.), and 2 amphipods (Isocyamus delphini and Cyamus boopis) were found. This paper presents 6 new geographic records of macroparasites from cetaceans in temperate Atlanto-Iberian waters. A total of 11 component parasite species were found, mainly parasitizing the blubber, mesentery and stomach of cetaceans. Cetaceans harboured a suite of 4 generalist and 8 specialist species.
\end{abstract}

KEY WORDS: Macroparasites Stranded cetaceans · NW Spain

\section{INTRODUCTION}

Several unusual mass mortalities of marine mammals around the world have been linked to environmental deterioration involving bioaccumulation of pollutants (trace metals and organo-halogenated compounds) (Wageman \& Muir 1984, Tanabe et al. 1994, Viale 1994, Aguilar et al. 1995) and virus-induced epizootics (Geraci et al. 1982, Domingo et al. 1990). A high intake of xenobiotics could cause, directly or indirectly, impairment of immune responses to other common pathogens (bacteria, fungi and parasites), causing severe intercurrent disease outbreaks in wild populations. Nevertheless, in many instances it has been difficult to establish the link between morbidity and mortality of individuals and populations and exposure to parasites (Geraci \& St. Aubin 1987).

\footnotetext{
- Addressee for correspondence.

E-mail: spascual@setei.uvigo.es
}

During the period 1990 to 1996, the Galician Coordinating Body for the Study of Marine Mammals (C.E.M.MA.) compiled a total of 776 references to marine mammals found stranded or accidentally caught in the northwestern Spanish Atlantic waters (López et al. 1996). This data represents $75 \%$ of total stranded marine mammals found on $2750 \mathrm{~km}$ of the North Iberian Peninsula coast (from the Bidasoa river, French border, to the Miño Estuary, Potuguese border). Despite this, no attention has been given to their parasitefauna composition.

Although the Galician coast is probably an important area for cetacean strandings, comparative data on parasitic disease prevalence has not been reported. This study provides the first information on host-parasite data for marine mammals off the NW Iberian Peninsula coast. This paper thus provides new data for monitoring transfers and bioaccumulation of parasites in wild marine organisms and for studying the adjustment of heteroxenous parasite life-cycles to the Galician food web. 


\section{MATERIALS AND METHODS}

During the period February 1991 to October 1996, a total of 80 toothed and baleen whale specimens (Table 1) which were stranded on the shores of the Galician coast (NW Spain), either floating in the water or entangled in fishing nets, were systematically surveyed for ectoparasites or epizoics and endoparasites. Cetaceans were sampled at 6 localities (Fig. 1).

Sex and standard body length (BL, to the nearest $\mathrm{cm}$ ) of each host animal were recorded in the field. When possible, animals were taken to the laboratory and weighed (total body weight, BW, to the nearest $\mathrm{kg}$ ).

The investigation was restricted to the macroparasite (platyhelminths, nematodes, acanthocephalans and crustaceans) fauna of cetaceans according to Rohde (1993). Blubber layer, mesenteries, kidneys and air sinuses were examined during necropsy in the field. Digestive systems and lungs were collected and immediately frozen. The intestines, stomach compartments, bile and pancreatic ducts, bronchi and bronchioles were split open and examined and processed by parasitological techniques, according to the recommendations by Borgsteede (1991).

Species were assigned to the categories of specialist or generalist. Specialists were defined as species re-

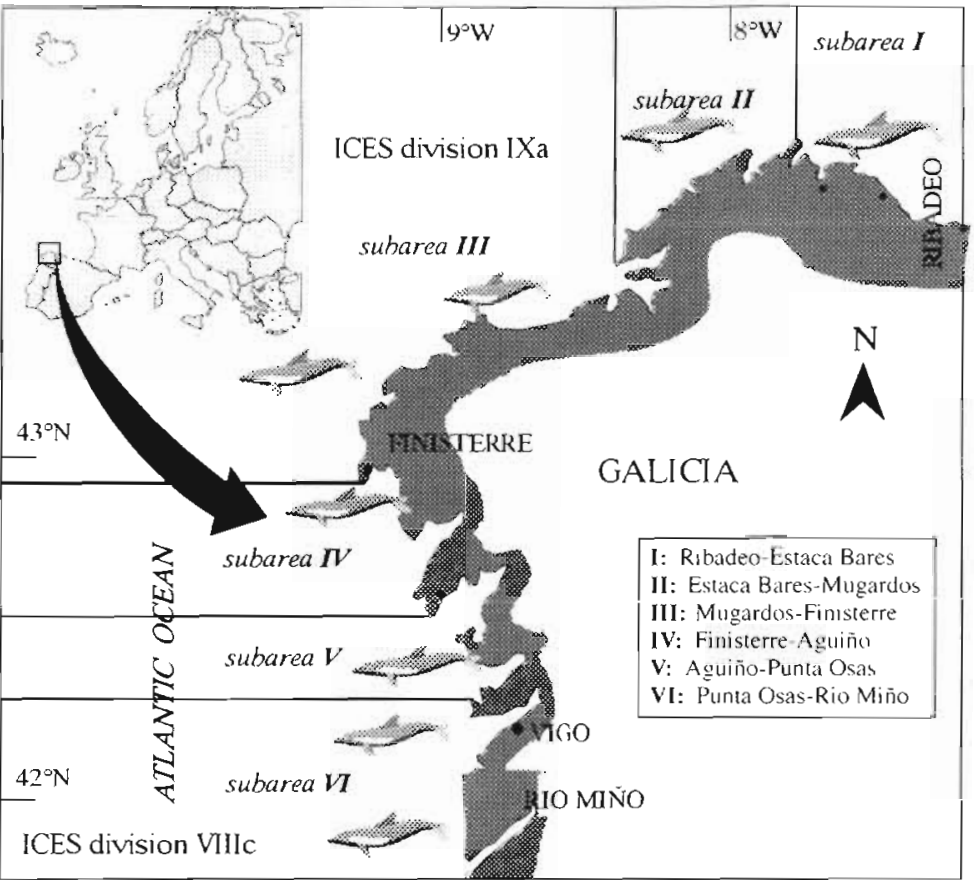

Fig. 1. Sampling subareas on the shores of Galicia, Spain

stricted in distribution to their host cetacean species. Generalists are species that are regularly found in several genera or families of cetaceans (Kennedy 1995). Ecological terms referring to the parasites follow Margolis et al. (1982) and Bush et al. (1997). Based on prevalence values, parasitic metazoa were also classified into component $(\mathrm{p}>10 \%)$ and secondary species

Table 1. Host species, sampling date and reference codes for hosts and sampling locations. The number of host individuals (N), standard body length $(B L:$ mean $\pm S D$ ) and total body weight $(B W:$ mean \pm SD) are also provided. -: no data

\begin{tabular}{|c|c|c|c|c|c|c|}
\hline $\begin{array}{l}\text { Host } \\
\text { species }\end{array}$ & $\begin{array}{l}\text { Host } \\
\text { reference } \\
\text { code }\end{array}$ & $\begin{array}{l}\text { Area } \\
\text { reference } \\
\text { code }\end{array}$ & $\begin{array}{l}\text { Sampling } \\
\text { date }\end{array}$ & $\mathrm{N}$ & $\begin{array}{l}\mathrm{BL} \\
(\mathrm{cm})\end{array}$ & $\begin{array}{l}\mathrm{BW} \\
(\mathrm{kg})\end{array}$ \\
\hline $\begin{array}{l}\text { Delphinus delphis } \\
\text { (common dolphin) }\end{array}$ & DD & III, IV, V, VI & Jan 1991-Oct 1996 & 50 & $\begin{array}{r}189.5 \pm 21.6 \\
(135-230)\end{array}$ & $\begin{array}{l}74.3 \pm 28.9 \\
(36.3-150)\end{array}$ \\
\hline $\begin{array}{l}\text { Stenella coeruleoalba } \\
\text { (striped dolphin) }\end{array}$ & $\mathrm{SC}$ & III, V, VI & Dec 1992-Sep 1996 & 8 & $\begin{array}{r}194.3 \pm 31.1 \\
(154-225)\end{array}$ & - \\
\hline $\begin{array}{l}\text { Tursiops truncatus } \\
\text { (bottle-nosed dolphin) }\end{array}$ & TT & II, III, IV, V & Nov 1992-Oct 1996 & 10 & $\begin{array}{r}279.5 \pm 25.7 \\
(240-310)\end{array}$ & - \\
\hline $\begin{array}{l}\text { Grampus griseus } \\
\text { (Risso's dolphin) }\end{array}$ & GG & III, VI & Dec $1994-J$ ul 1996 & 2 & $\begin{array}{r}299.5 \pm 7.8 \\
(294-305)\end{array}$ & - \\
\hline $\begin{array}{l}\text { Globicephala melas } \\
\text { (long-finned pilot whale) }\end{array}$ & GM & $\mathrm{I}, \mathrm{VI}$ & Apr 1993-Dec 1995 & 4 & $\begin{array}{r}384.2 \pm 82.2 \\
(286-469)\end{array}$ & - \\
\hline $\begin{array}{l}\text { Kogra breviceps } \\
\text { (pigmy sperm whale) }\end{array}$ & $\mathrm{KB}$ & II & Oct 1995 & 1 & 258 & - \\
\hline $\begin{array}{l}\text { Phocoena phocoena } \\
\text { (harbour porpoise) }\end{array}$ & PP & IV, VI & Nov 1992-Dec 1994 & 4 & $\begin{array}{r}182.7 \pm 16.1 \\
(168-202)\end{array}$ & - \\
\hline $\begin{array}{l}\text { Megaptera novaeangliae } \\
\text { (humpback whale) }\end{array}$ & $\mathrm{MN}$ & III & Mar 1993 & 1 & 490 & - \\
\hline
\end{tabular}


$(10 \% \geq p>1 \%)$ (Bush et al. 1990). Frequency distributions of parasitized organs were calculated within and between host groups. Representative specimens of each parasite species have been deposited in the Department of Parasitology at the University of Vigo (Spain)
$54.2 \%$ in other Delphinidae and $71.4 \%$ in other cetaceans) with a mean of 1.2 parasitic species (range: 1 to 3) per host. Nematodes comprised $61.5 \%$ of the total parasitic sample. The sibling species complex Anisakis simplex (Nascetti et al. 1986) was the most frequent nematode, comprising $12.5 \%$ of all nematode species.

\section{RESULTS}

The taxonomic and systematic studies have enabled the identification of 12 metazoan endo- or ectoparasitic species (Table 2). Larval phylobothriid worms were the most common tissue parasites found in cetaceans. Host range varied from 6 (Phyllobothrium delphini) to 4 odontocetes (Monorygma grimaldii). A total of 14.4 (range: 1 to 47 ) individuals of $P$. delphini were usually found in the subcutaneous fat (mainly in the urogenital zone), which comprised 18.2 to $33.6 \%$ of the infested organs (Fig. 2). Cysts of $M$. grimaldii were found singly or in groups with 13.5 (range: 2 to 32 ) cysts on the outer surfaces of mesentery membranes in the body cavity (26.7 to $27 \%$ of the infested organs). Nematodes of the family Pseudaliidae infested lungs and air sinuses of the Delphinidae. All nematodes found in the pharynx, oesophagus and stomach belonged to the Anisakidae. Within the genus Anisakis (Dujardin 1845), 2 common species were found: $A$. simplex (which had the highest prevalence) and $A$. physeteris; these parasitized 6 and 1 host species, respectively. A single species of crassicaudid nematode (Crassicauda magna) was found infesting the musculature in the neck area of Kogia breviceps. Among the crustacean species, 2 amphipods, Isocyamus delphini and Cyamus boopis, were identified in natural openings and wounds of the skin, mainly parasitizing the genital slit of the Risso's dolphin and humpback whale, respectively.

Two common dolphins were free of parasitic metazoa, while $97.5 \%$ of cetaceans were infested with 1 to 4 parasite species (mean 2.04 to 2.2 in Delphinidae and 1.67 for other cetaceans). Sixty-eight percent of the cetaceans were infested with cestodes $(74 \%$ in Delphinus delphis, $66.7 \%$ in other Delphinidae and $28.6 \%$ in other cetaceans). This comprised $15.4 \%$ of all parasitic metazoan parasites. Nematode infestations occurred in $65.4 \%$ of the cetaceans $170 \%$ in $D$. delphis,
Table 2. Taxonomic information, host and site location, and prevalence (P) of infestation of the macroparasites found in cetaceans from NW Spain. Host-reference codes defined in Table 1. Sites: as, air sinuses; bb, blubber; lu, lungs; mm, mesentery; na, neck area; oe, oesophagous; ph, pharynx; sk, skin; st, stomach

\begin{tabular}{|c|c|c|c|}
\hline Parasite & Host & Site & $\mathrm{P}(\%)$ \\
\hline \multicolumn{4}{|l|}{ Cestoda (tapeworms) } \\
\hline $\begin{array}{l}\text { Phyllobothrium delphini } \\
\text { (Bosc, 1802) (plerocercoid) }\end{array}$ & $\begin{array}{l}\mathrm{DD}^{\mathrm{c}} \\
\mathrm{SC}^{\mathrm{c}} \\
\mathrm{TT}^{\mathrm{c}} \\
\mathrm{GG}^{\mathrm{c}} \\
\mathrm{GM}^{\mathrm{c}} \\
\mathrm{KB}^{\mathrm{c}}\end{array}$ & $\begin{array}{l}\mathrm{bb} \\
\mathrm{bb} \\
\mathrm{bb} \\
\mathrm{bb} \\
\mathrm{bb} \\
\mathrm{bb}\end{array}$ & $\begin{array}{l}70 \\
87.5 \\
50 \\
50 \\
25 \\
100\end{array}$ \\
\hline $\begin{array}{l}\text { Monorygma grimaldii }{ }^{\mathrm{d}} \\
\text { (Moniez, } 1889 \text { ) (plerocercoid) }\end{array}$ & $\begin{array}{l}\mathrm{DD} \\
\mathrm{SC}^{\mathrm{c}} \\
\mathrm{TT}^{\mathrm{c}} \\
\mathrm{KB}^{\mathrm{c}}\end{array}$ & $\begin{array}{l}\mathrm{mm} \\
\mathrm{mm} \\
\mathrm{mm}\end{array}$ & $\begin{array}{r}42 \\
75 \\
50 \\
100\end{array}$ \\
\hline \multicolumn{4}{|l|}{ Nematoda (roundworms) } \\
\hline $\begin{array}{l}\text { Anisakis simplex (Rudolphi, 1809) } \\
\text { (larvae and adults) }\end{array}$ & $\begin{array}{l}\mathrm{DD}^{\mathrm{c}} \\
\mathrm{SC}^{\mathrm{c}} \\
\mathrm{TT}^{\mathrm{c}} \\
\mathrm{GM}^{\mathrm{c}} \\
\mathrm{KB}^{\mathrm{c}} \\
\mathrm{PP}^{\mathrm{c}}\end{array}$ & $\begin{array}{l}\text { st } \\
\text { st } \\
\text { ph, oe, st } \\
\text { st } \\
\text { ph, oe, st } \\
\text { st }\end{array}$ & $\begin{array}{l}64 \\
37.5 \\
60 \\
75 \\
100 \\
75\end{array}$ \\
\hline $\begin{array}{l}\text { Anisakis physeteris }{ }^{b} \\
\text { (Baylis, 1923) (larvae and adults) }\end{array}$ & $\mathrm{KB}^{\mathrm{C}}$ & ph, oe, st & 100 \\
\hline $\begin{array}{l}\text { Crassicaudidae } \\
\text { Crassicauda magnab } \\
\text { (Dollfus, 1966) (adult) }\end{array}$ & $\mathrm{KB}^{\mathrm{c}, \mathrm{dt}}$ & na & 100 \\
\hline $\begin{array}{l}\text { Pseudaliidae } \\
\text { Halocercus delphini } \\
\text { (Baylis \& Daubney, 1925) (adults) }\end{array}$ & $\begin{array}{l}D D^{c, d} \\
T T^{e}\end{array}$ & $\begin{array}{l}\text { lu } \\
\text { lu }\end{array}$ & $\begin{array}{l}18 \\
10\end{array}$ \\
\hline 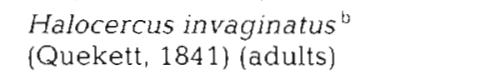 & $\mathrm{PP}^{\mathrm{r}}$ & lu & 25 \\
\hline $\begin{array}{l}\text { Halocercus spp. } \\
\text { (Baylis \& Daubney, 1925) (adults) }\end{array}$ & $\mathrm{SC}^{\mathrm{c} d \mathrm{~d}}$ & lu & 25 \\
\hline $\begin{array}{l}\text { Stenurus globicephalae } \\
\text { (Baylis \& Daubney, 1925) (adults) }\end{array}$ & $\mathrm{GM}^{\mathrm{c}}$ & as & 50 \\
\hline \multicolumn{4}{|l|}{ Acanthocephala (thorny-headed worms) } \\
\hline $\begin{array}{l}\text { Bolbosoma sp. } \\
\text { (Porta, 1908) (adults) }\end{array}$ & $\mathrm{DD}^{\mathrm{d}, \mathrm{e}}$ & st & 4 \\
\hline \multicolumn{4}{|l|}{ Crustacea (whale-lice) } \\
\hline $\begin{array}{l}\text { Isocyamus delphini }{ }^{b} \\
\text { (Guérin-Méneville, 1837) (adults) }\end{array}$ & $\mathrm{GG}^{\mathrm{c}, \mathrm{d}}$ & sk & 50 \\
\hline $\begin{array}{l}\text { Cyamus boopis } \\
\text { (Lütken, 1870) (larvae and adults) }\end{array}$ & MNed & sk & 50 \\
\hline \multicolumn{4}{|c|}{$\begin{array}{l}{ }^{a} \text { Generalist species; }{ }^{b} \text { specialist species; }{ }^{c} \text { component species; }{ }^{d} \text { first } \\
\text { record of this parasite on this host in temperate water of the NE } \\
\text { Atlantic Ocean; }{ }^{e} \text { secondary species }\end{array}$} \\
\hline
\end{tabular}




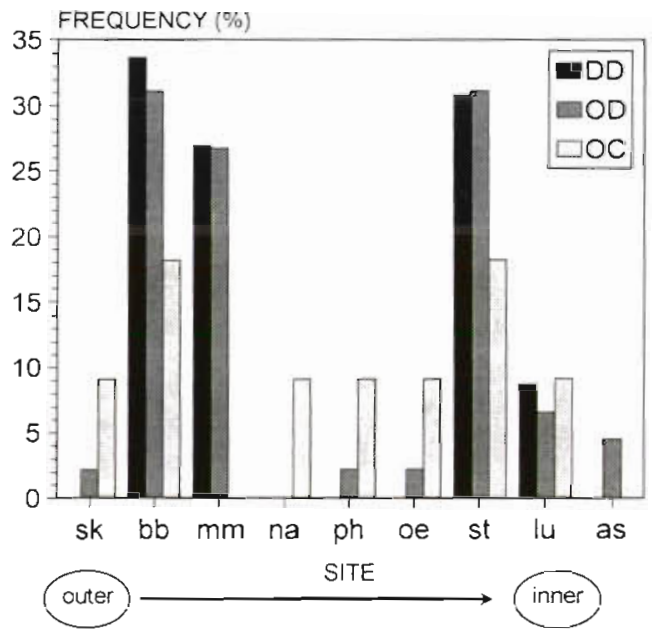

Fig. 2. Frequency distribution of parasitized organs in cetaceans from NW Spain. Sites: sk, skin; bb, blubber; mm, mesentery; na, neck area; ph, pharynx; oe, oesophagous; st, stomach; lu, lungs; as, air sinuses. DD: Delphinus delphis; OD: other Delphinidae; OC: other cetaceans

Acanthocephalan infestations occurred in $3.7 \%$ of the cetaceans, comprising $7,7 \%$ of the total parasitic sample. Cyamids of the species Isocyamus delphini and Cyamus boopis occurred in $2(2.5 \%)$ cetacean individuals. Prevalences varied from $0 \%$ in $D$. delphis to $4.2 \%$ in other Delphinidae and to $14.3 \%$ in the other cetaceans. Nematoda was clearly the most prevalent taxonomic group: 7 species within the Anisakidae, Crassicaudidae and Pseudaliidae were found in both cetacean suborders

\section{DISCUSSION}

Many of the parasites recovered in this study have been reported previously. However, the nematodes Crassicauda magna, Halocercus delphini, and Halocercus spp., the acanthocephalan of the genus Bolbosoma and the cyamids Isocyamus delphini and Cyamus boopis are reported for the first time from 5 cetacean species from temperate waters of the northeartern Atlantic coast.

Parasites species richness is well within the ranges given for endothermic vertebrates (Kennedy et al. 1986, Pence 1990). Cetaceans harboured the same number of component helminth parasite species as those found by Bush et al. (1990) in an analysis of patterns of community richness among parasitic helminth communities in aquatic mammals. The common dolphin harbours a similar number of parasite species, as do other Delphinidae, since no marked differences in host factors (complexity of the digestive tract, vagility, diet complexity, selective versus-non selective feeding on appropriate intermediate hosts) (Kennedy et al. 1986, Balbuena \& Raga 1993) are likely.

A comparison of common dolphin and other Delphinidae parasite-faunas indicated that their respective parasite component communities were, to some extent, similar $(67 \%)$ with a high overlap of parasitic metazoan species. In Galician waters, available data suggests that dolphins are primarily fish-eaters (mostly blue-whiting Micromesistius poutassou) which take prey they encounter rather than selecting particular prey items (González et al. 1994). Similarity in trophic specialization of small cetaceans in the sampling area may lead to their helminthofauna similarity. Major differences in patterns of community richness and less parasite-fauna similarity were found between dolphins and other cetaceans, which probably shows the interacting influence of host ecology and host evolution in determining community richness, as previously proposed for other cetacean species (Balbuena \& Raga 1993, Aznar et al. 1994).

Acknowledgements. The authors are very grateful to many people who reported stranded animals and those who helped by storing or transporting sperimens, particularly the staff of the C.E.M.MA. Thanks are also due to Xunta de Galicia for financial support under Project XUGA30110A97.

\section{LITERATURE CITED}

Aguilar A, Borell A, Pastor T (1995) Factors affecting variability of persistent pollutants levels in cetaceans. Bergen, 27-29 March 1995. Working paper. SC/M95/P6

Aznar FJ, Balbuena JA, Raga JA (1994) Helminth communities of Pontoporia blainvillei (Cetacea: Pontoporiidae) in Argentinian waters. Can J Zool 72:702-706

Balbuena JA, Raga JA (1993) Intestinal helminth communities of the long-finned pilot whale (Globicephala melas) off the Faroe Islands. Parasitol 106:327-333

Borgsteede F (1991) Parasitological examination. In: Kuiken T, García Hartmann M (eds) Proceedings of the first ECS workshop on cetacean pathology: dissection techniques and tissue sampling. European Cetacean Society Newsletter No. 17, Special issue. Leiden, p 11-16

Bush AO, Lafferty KD, Lotz JM, Shostak AW (1997) Parasitology meets ecology on its own terms: Margolis et al. revis ited. J Parasitol 83:575-583

Bush AO, Aho JM, Kennedy CR (1990) Ecological versus phylogenetic determinants of helminth parasite community richness. Evol Ecol 4:1-20

Domingo $M$. Ferrer L, Pumarola $M$, Marco A, Plana J, Kennedy S, McAliskey M, Rima BK (1990) Morbillivirus in dolphins. Nature 336:21

Geraci JR, St. Aubin DJ (1987) Effects of parasites on marine mammals. Int J Parasitol 17:407-414

Geraci JR, St. Aubin DJ, Barker IK, Webster RG, Hınshaw VS, Bean WJ, Ruhnke HL, Prescott JH, Early G, Baker SS Madoff S, Schooley RT (1982) Mass mortality of harbour seals: pneumonia associated with influenza $A$ virus Science 215:1129-1131

Gónzalez AF, López A, Guerra A, Barreiro A (1994) Diets of marine mammals on the northwestern Spanish Atlantic 
coast with special reference to Cephalopoda. Fish Res 21: $179-191$

Kennedy CR (1995) Richness and diversity of macroparasite communities in tropical eels Anguilla reinhardtii in Queensland, Australia. Parasitol 111:233-245

Kennedy CR, Bush AO, Aho JM (1986) Patterns in helminth communities: why are birds and fish different? Parasitol 93:205--215

López A, Cendrero O, Pérez C. García-Castrillo G (1996) Mamiferos mariños varados no norte e noroeste Español no 1995. International Council for the Exploration of the Sea. Marine Mammals Committee. CM 1996/N:9

Margolis L, Esch GW, Holmes JC, Kuris AM, Schad GA (1982) The use of ecological terms in parasitology (report of an ad hoc committee of the American Society of Parasitologists). J Parasitol 68:131-133

Nascetti G, Paggi L, Orecchia P, Smith JW, Mattiucci S, Bullini L (1986) Electrophoretic studies on the Anisakis simplex complex (Ascaridida: Anisakidae) from the Medi-

Editorial responsibility: Murray Dailey,

Gunnison, Colorado, USA terranean and North-east Atlantic. Int J Parasitol 16(6): $633-640$

Pence D (1990) Helminth communities of mammalian hosts: concept at the infracommunty, component and compound community levels. In: Esch GW, Bush AO, Aho JM (eds) Parasite communities: patterns and processes. Chapman and Hall, London, p 21-40

Rohde K (1993) Ecology of marine parasites. CAB International, Wallingford, p 5-16

Tanabe $\mathrm{S}$, Iwath $\mathrm{H}$, Tatsukawa R (1994) Global contamination by persistent organochlorines and their ecotoxicological impact on marine mammals. Sci Total Environ 154:163-177

Viale D (1994) Cetaceans as indicators of a progressive degradation of Mediterranean water quality. Int Environ Stud 45:182-195

Wageman R, Muir DGC (1984) concentrations of heavy metals and organochlorines in marine mammals of northern waters: overview and evaluation. Can Tech Rep Fish Aquat Sci 1279:1-97

Submitted: May 23, 1997; Accepted: December 12, 1997 Proofs received from author(s): February 26, 1998 